\title{
BORE-HOLE SURVEY AT DYE 3, SOUTH GREENLAND
}

\author{
By N. S. Gundestrup \\ (Geophysical Isotope Laboratory, University of Copenhagen, Haraldsgade 6, DK 2200 Copenhagen N, Denmark) \\ and B. LyLe HANSEN
}

(Polar Ice Coring Office, University of Nebraska-Lincoln, 329 North 12th Street, Lincoln, Nebraska 68588-0200, U.S.A.)

\begin{abstract}
Aвstract. In 1983 three directional surveys were made in the bore hole from which a deep ice core was obtained in the summers of 1979-81. The inclination and azimuth of the bore hole were measured on three surveys, temperature was included on two surveys, fluid pressure and hole diameter on one of the surveys. Fluid-pressure measurements show that the iceoverburden pressure was undercompensated in the upper few hundred meters and overcompensated at the bottom of the hole. Diameter measurements show closure in the upper portion and expansion near the bottom beginning at the transition from the Holocene to Wisconsin ice at $1784 \mathrm{~m}$. The hole expansion and increase in inclination correlate with dust and silt content in the Wisconsin ice. Changes in azimuth are due to flow of the ice and are consistent with the direction of flow at the surface. Temperature measurements show that the hole is at or near equilibrium. The gradient of $0.012 \mathrm{~K} / \mathrm{m}$ below $1400 \mathrm{~m}$ is less than the $0.018 \mathrm{~K} / \mathrm{m}$ at Camp Century. There is a slight reduction in gradient near the bottom from internal friction in the silty ice.
\end{abstract}

Résumé. Relevés du trou de forage à Dye 3, Groenland du Sud. En 1983, trois relevés de direction ont été réalisés dans le trou de forage à partir duquel des carottes profondes avaient été obtenues pendant les hivers de 1979 à 1981. Les inclinaisons et l'azimut du forage ont été mesurées pour trois relevés, la température pour deux relevés, la pression du fluide et le diamètre du trou au cours d'un des relevés. Les mesures de pression du fluide montrent que l'excès de pression de la glace était sous-compensée dans les quelques premières centaines de mètres et sur-compensée au fond du forage. Les mesures de diamètre montrent une fermeture dans la partie supérieure et un aggrandissement au fond, débutant à la transition entre l'Holocène au Wisconsin à $1784 \mathrm{~m}$. L'agrandissement du trou et l'augmentation en incli-

\section{INTRODUCTION}

In the summers of 1979 to 1981 , a deep (2037.63 m) ice core was obtained at Dye 3 (1at. $65^{\circ} 11$ 'N., long. $43^{\circ} 49^{\prime} \mathrm{W} ., \mathrm{H}=2490 \mathrm{~m}$ ) in south Greenland. The drill site is on the eastern side of the ice sheet, in an area with a mountainous bedrock topography (Overgaard and Gundestrup, in press). The top $81.7 \mathrm{~m}$ was drilled thermally and cased with steel pipe by the Cold Regions Research and Engineering Laboratory (CRREL) (Rand, 1980), and the hole was drilled from $81.7 \mathrm{~m}$ to the bottom with an electromechanical drill (Gundestrup and others, in press). The drill, using neither melting nor solvents, produces a hole with a uniform diameter. The hole is filled with a liquid in order to minimize hole closure from the overburden pressure of the ice.

After the drilling stopped in 1980 at $901 \mathrm{~m}$, a temperature profile was measured. Shortly before the end of the 1981 season, an inclination profile (Gundestrup and others, in press) was obtained using the inclinometers in the drill. The next day the drill was trapped at the bottom while drilling in silty ice. Four hundred liters of perchlorethylene (PCE) were added to the hole, and the drill was left with tension in the cable. In 1982, the drill had become loose. After recovery of the drill, a temperature profile was measured. Sonic logging was performed (Taylor, unpublished) and a $5 \mathrm{~m}$ by $0.08 \mathrm{~m}$ probe was used as radar target in an attempt to measure the azimuth of the hole inclinations, and the velocity of radar waves in ice (Jezek and Roeloffs, 1984). In 1983 three independent bore-hole surveys were made using different tools to measure inclina- naison sont corréles avec la teneur en poussière et en sédiments de la glace du Wisconsin. Le changement en azimut est dû à l'écoulement de la glace et concorde avec la direction de l'écoulement en surface. Les mesures de températures montrent que le trou est à ou proche de l'équilibre. Le gradient de $0,012 \mathrm{~K} / \mathrm{m}$ au-dessous de $1400 \mathrm{~m}$ est inférieur au $0,018 \mathrm{~K} / \mathrm{m}$ de Camp Century. Il y a une légère diminution du gradient près du fond dû au frottement interne de la glace chargée en sédiments.

Zusammenfassung. Bohrlochvermessung bei Dye 3, Süd-Grönland. Im Jahre 1983 wurden drei Richtungsmessungen in dem Bohrloch vorgenommen, aus dem in den Sommern 1979-81 ein tiefreichender Eiskern geborgen worden war. Neigung und Azimut des Bohrloches wurden dreimal eingemessen, bei zwei Vermessungen wurde die Temperatur mitbeobachtet, bei einer Vermessung auch der Flüssigkeitsdruck und der Lochdurchmesser. Die Messungen des Flüssigkeitsdrucks zeigen, dass der Auflagedruck des Eises in den obersten Hektometern unterkompensiert, am Grunde des Bohrloches hingegen überkompensiert ist. Die Durchmessermessungen erge'.en eine Schliessung im oberen Teil und eine Erweiterung nahe dem Grund, beginnend am Übergang vom holozänen zum Wisconsin-Eis bei $1784 \mathrm{~m}$. Die Locherweiterung und die Zunahme der Neigung fallen mit dem Gehalt an Staub und Schlamm im Wisconsin-Eis zusammen. Azimutänderungen sind durch den Fluss des Eises verursacht und passen mit der Fliessrichtung an der Oberfläche zusammen. Temperaturmessungen zeigen, dass sich das Loch ganz oder nahezu im Gleichgewicht befindet. Der Gradient von $0,012 \mathrm{~K} / \mathrm{m}$ unterhalb von $1400 \mathrm{~m}$ ist geringer als der von $0,018 \mathrm{~K} / \mathrm{m}$ bei Camp Century. Eine geringe Abnahme des Gradienten tritt nahe dem Grunde infolge der inneren Reibung im schlammigen Eis auf.

tion and azimuth. The hole diameter, fluid temperature, and pressure were also measured.

While drilling, depth was measured as accumulated core length. The hole length changes with time due to the ice movement. In this work all slant hole depths measured on the logging winch in 1983 were scaled to comply with the 1981 core length which we believe to be the most accurate measurement of the length of the hole. This corresponds to a true vertical depth (TVD) of $2033.2 \mathrm{~m}$ as the difference between slant hole length and TVD was $4.4 \mathrm{~m}$ in 1981. In 1983, the difference was $7.4 \mathrm{~m}$.

At the end of the 1983 season the casing was extended $2.29 \mathrm{~m}$ and 416 liters of diesel fuel was added to the hole.

\section{EQUIPMENT}

The temperature profiles measured in 1980 and 1982 were obtained with a lightweight probe $5 \mathrm{~m}$ below the drill antitorque section used to weight the cable. The probe presses the temperature transducer against the wall of the bore hole and resembles the surface sampling device described by Bird ([C1976]). The temperature transducer - the same both years - was a thermistor (Fenwal type UUA 32J3) calibrated by the manufacturer to $0.03 \mathrm{~K}$ at $-40^{\circ} \mathrm{C},-20^{\circ} \mathrm{C}$, and $0^{\circ} \mathrm{C}$. Resolution of the measurements was $0.002 \mathrm{~K}$, and the sampling interval was $25 \mathrm{~m}$. Interpolation was performed using the equation (Steinhart and Hart, 1968):

$$
1 / T=A+B \ln R+C(\ln R)^{3}
$$


where $R$ is thermistor resistance and $T$ the absolute temperature. A, B, and C are constants. The first logging device used in 1983 was the University of Copenhagen (UCPH) experimental short unit $(1.10 \mathrm{~m}$ from center to bottom of tool) measuring inclination, azimuth, temperature, pressure, and diameter.

This tool employs the same principles as the ISTUK drill: all measurements are performed in the logger controlled by a microprocessor. At $4 \mathrm{~s}$ intervals, the microprocessor transmits the information to a standard computer terminal at the surface. Here, the data are stored on magnetic tape for subsequent analysis.

The temperature transducer is similar to the type used in 1980 and 1982, however it measured the temperature of the fluid near the center of the hole at the bottom of the tool. The resolution of the sensor is $0.012 \mathrm{~K}$.

Inclination is measured with a pair of Schaevitz LSRP-14.5 inclinometers, compensated to work from $-50^{\circ} \mathrm{C}$ to $0^{\circ} \mathrm{C}$. The nominal range of the inclinometers is $14.5^{\circ}$. Azimuth is measured with a magnetic compass (Aanderaa, type 1248).

The pressure transducer is a quartz sensor (Paroscientific type $75 \mathrm{k}-002$ ), calibrated by the manufacturer with an accuracy of 0.04 per cent of the reading at $21^{\circ} \mathrm{C}$ and $-25^{\circ} \mathrm{C}$.

The tool has two calipers, one at each end. Due to a friction problem, only the lower caliper was operative. The caliper centers the tool using three points of contact with the hole wall. The range of measurements is 98-136 mm with a resolution of $0.1 \mathrm{~mm}$.

The second logging device was owned and operated by "Sperry-Sun" of Canada. They used a gyro-accelerometer combination to give both inclination and azimuth. The distance from center to bottom of tool is $2.46 \mathrm{~m}$.

The last logging device used was the Polar Ice coring office (PICO) survey tool. The compass and inclinometer are of the same brand and type as those used in the UCPH tool. In addition, a temperature transducer (thermistor) was mounted $0.25 \mathrm{~m}$ below the main body of the tool. The thermister (no. 1297) was calibrated at CRREL to $0.01 \mathrm{~K}$ at the following temperatures: $-78.685^{\circ} \mathrm{C},-38.867^{\circ} \mathrm{C}, 0.01^{\circ} \mathrm{C}$, and $40.780^{\circ} \mathrm{C}$. The resistance of the thermistor was converted to degrees Celsius using the calibration table for that thermistor. A rotary selector switch in the survey tool was actuated from the surface and the outputs of the various transducers were measured with a highaccuracy digital multimeter. The distance from the center to the bottom of the tool is $2.25 \mathrm{~m}$.

A Gearhart-0wen 800 SUA winch was used for the three surveys. The winch has a hydrostatic drive powered by a diesel engine and is equipped with approximately $4000 \mathrm{~m}$ of prestressed seven-conductor steel-armoured logging cable $8 \mathrm{~mm}$ in diameter, a depth counter reading in feet, and a cable tension meter.

\section{MEASUREMENTS}

\section{Hole liquid density}

Using the measured depth of the logging tool and the pressure measured by it at that depth, the density of the hole liquid was calculated. The curve is slightly smoothed, the primary noise source being the resolution of the pressure gauge, approximately $1 \mathrm{~m}$ of depth. The density profile (Fig. 1) has three distinct regions; the density decreases from the surface of the liquid down to a depth of about $800 \mathrm{~m}$, from $800-1800 \mathrm{~m}$ the density is nearly constant, then the density increases with depth. The high density in the upper region is caused by the excess 4001 iters of PCE added in 1981. Two years later this PCE has only reached a depth of $800 \mathrm{~m} !$ The center region has a density close to $950 \mathrm{~kg} / \mathrm{m}^{3}$ which was the nominal density chosen to compensate for the lack of liquid in the casing (the casing leaks at $68 \mathrm{~m}$ ) and to produce

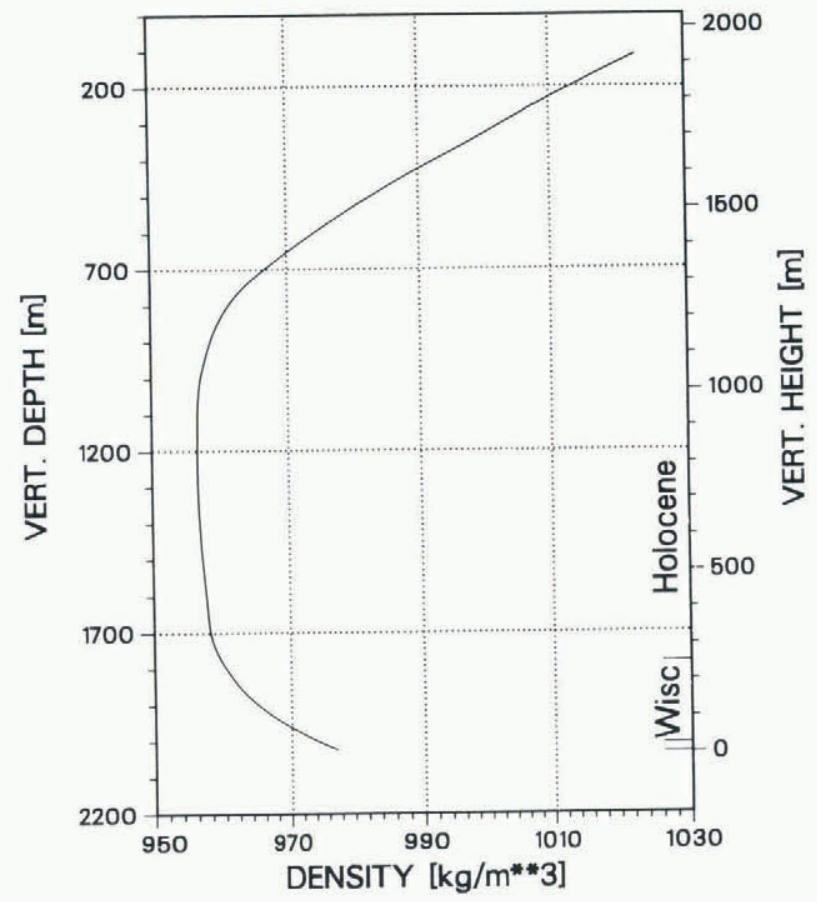

Fig. 1. Hole-liquid density versus true vertical depth as measured in 1983. The upper high density is due to excess amount of heavy liquid added in 1981.

the correct pressure at the bottom of the hole. Repeated measurements showing the change in density with time may indicate the reason why the density increases with depth in the lower part of the hole.

\section{Hole pressure}

Due to addition of excess PCE in 1981, and a few hundred liters of diesel fuel in 1982, the pressure at the bottom should be at or above the hydrostatic pressure of the ice. This is confirmed by the diameter measurements. The absolute pressure $2 \mathrm{~m}$ above the bottom of the hole was 183.65 bars. The total vertical depth of the hole is $2033.2 \mathrm{~m}$. Using a density correction for the firn of $24 \mathrm{~m}$, and a barometric pressure of $0.74 \mathrm{bar}$, an average ice density of $928 \pm 2 \mathrm{~kg} / \mathrm{m}^{3}$ is calculated assuming that the liquid at the bottom is in hydrostatic equilibrium with the ice. This value is significantly higher than the $917-920 \mathrm{~kg} / \mathrm{m}^{3}$ measured on the Byrd core (Gow, 1970). The difference is probably due to lack of hydrostatic equilibrium at the bottom. However, the Byrd density was measured on relaxed ice-core samples. These samples may have a low density due to formation of air bubbles. Future measurements can give the in situ ice density.

\section{Diameter}

The diameter was measured with a three-point caliper mounted $20 \mathrm{~cm}$ above the bottom of the UCPH tool which measures the diameter continuously and stores the maximum and minimum values. Every four seconds these values are transmitted to the surface and a new search for diameter extremes is initiated. Thus, any diameter anomaly will be detected. Apart from the caliper itself, errors may be introduced by accretion of ice on the caliper.

Figure 2 shows the measured diameter. Above $150 \mathrm{~m}$, the diameter exceeds the maximum range of $136 \mathrm{~mm}$. The spikes between $800 \mathrm{~m}$ and $900 \mathrm{~m}$ are caused by slippage of the antitorque springs during drilling. At $700 \mathrm{~m}$ the ice core started to be brittle, and at $800 \mathrm{~m}$ the ice core had several fractures. In an (unsuccessful) attempt to reduce these fractures, the drill rotation speed was slowed down. This reduction in drilling speed however disabled the fast automatic antitorque failure detector that normally would terminate the 


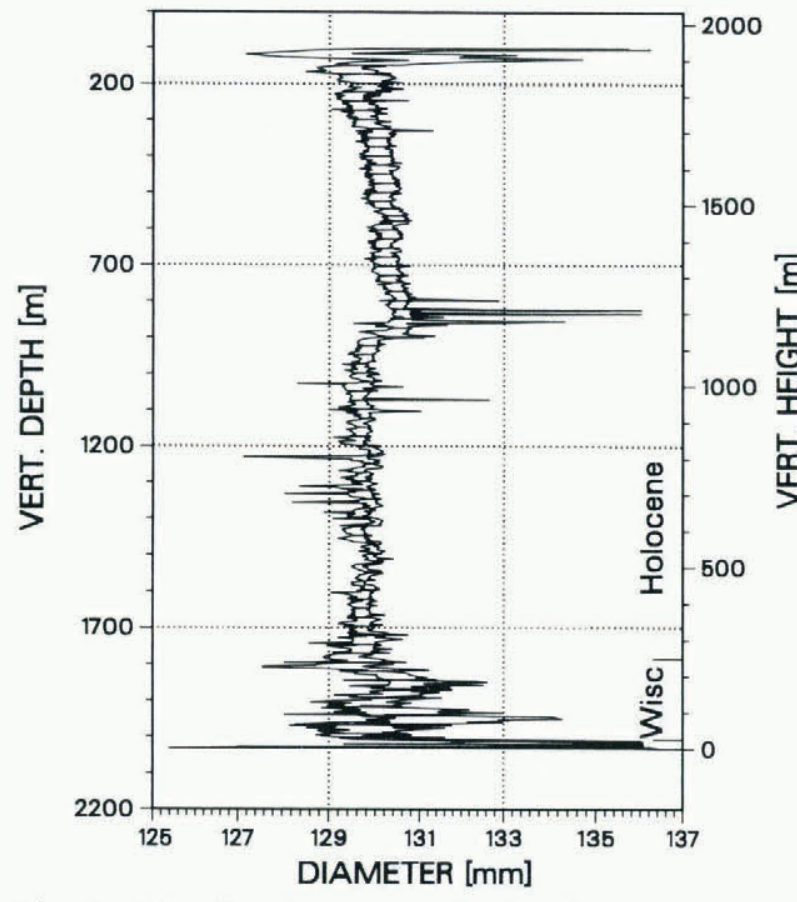

Fig. 2. Hole diameter versus depth. The two curves indicate the maximum and minimum diameters. The low diameter near the top is due to hydrostatic underpressure in the liquid-filled hole. The shift at $901 \mathrm{~m}$ indicates end of reaming. The hole is distorted in Wisconsin ice, e.g. below $1784 \mathrm{~m}$.

drilling. Thereafter the operator had to stop the drill in case of problems. The result is that the antitorque leaf spring scraped ice from the wall and in some positions increased the diameter beyond $136 \mathrm{~mm}$.

The nominal hole diameter is $129.5 \mathrm{~mm}$. In 1981 (before start of season) the diameter was reamed to $130 \mathrm{~mm}$ from the top down to $901 \mathrm{~m}$. The $0.5 \mathrm{~mm}$ shift at $901 \mathrm{~m}$ is clearly visible. The decrease in diameter from $900 \mathrm{~m}$ towards the top is caused by the hydrostatic underpressure due to the stand of the liquid being below the top of the casing.

Below $901 \mathrm{~m}$ until the Holocene-Wisconsin transition at $1783.74 \mathrm{~m}$ vertical depth, the diameter is within a few tenths of a millimeter of the nominal diameter. The negative spike at $1231 \mathrm{~m}$ is not reproducible, it was probably caused by ice on the caliper.

The diameter of the lowest part of the hole (Fig. 3 ) deviates significantly from the original $129.5 \mathrm{~mm}$. The PCE added in 1981 created a hydrostatic overpressure at the bottom of the hole up to 2.5 bars. This increase of the diameter caused by the overpressure starts at the transition from Holocene to Wisconsin. Part of the reason for the generally increasing diameter with depth in the Wisconsin ice is that the hydrostatic overpressure increases with depth.

The silty ice, starting at 2008.54 m vertical depth, has a diameter frequently exceeding $136 \mathrm{~mm}$. The curve to the left in Figure 3 is a dust profile measured as the mean of $55 \mathrm{~cm}$ of core (Hammer and others, in press). A high correlation between dust and increased diameters (soft ice) is visible. The diameter anomaly at 1944-1951 $\mathrm{m}$ is connected with a narrow, visible layer. This layer hardly shows up in the dust profile. The reason is probably that the layer consists of relatively large particles that were removed in the laser dust equipment. Furthermore, the layer is narrow, giving little contribution to the $55 \mathrm{~cm}$ average value. The dust content in silty ice exceeds the range of the equipment.

Five meters above the bottom there appears to be a short constriction reducing the hole diameter to

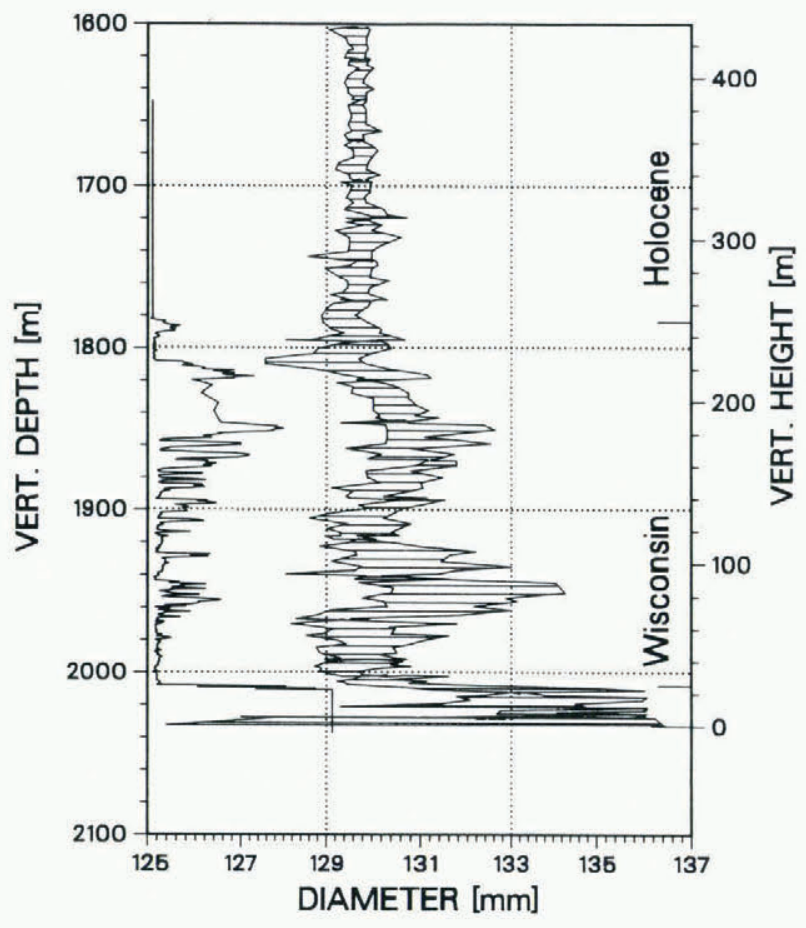

Fig. 3. Hole diameter versus depth below $1600 \mathrm{~m}$. The curve at left is a dust index. A high correlation between dust and hole deformation is visible.

$125.4 \mathrm{~mm}$. The constriction must have a relatively sharp edge as the logging tool tended to rest on the constriction. Having hydrostatic overpressure at that depth, the driving force cannot be the hydrostatic pressure difference between the ice and the liquid. We expect that the reason is a discontinuity in the ice creating a shift between the upper and the lower hole. If this explanation is correct, the lower $5 \mathrm{~m}$ of the hole will not be accessible in some years time.

\section{Temperat zose}

Temperatures were measured to the bottom of the hole, $901 \mathrm{~m}$, in 1980, in 1982, and twice in 1983. Figure 4 shows the measured profiles, including the profiles from 0-901 m as measured in 1980 and 1982 in an expanded temperature scale. Close to the surface, above $150 \mathrm{~m}$, the temperature profile is distorted due to the proximity of the steel casing. The cold peak around $200 \mathrm{~m}$ is assumed to be a climatic effect corresponding to a cold period 300 years ago (Dansgaard and others, 1975).

At $901 \mathrm{~m}$, the bottom of the hole in 1980, the temperature had increased $0.1 \mathrm{~K}$ from 1980 to 1982. The same temperature probe was used in 1980 and 1982. The temperatures measured in 1980 and 1982 in the depth interval 200-300 m are reproducible with an accuracy better than $0.01 \mathrm{~K}$, thus the shift is not caused by a measurement error.

After the drill was trapped at the bottom in 1981, power was removed from the dri11. The next day the eight temperature transducers in the drill measured the hole temperature to $-12 \pm 0.5^{\circ} \mathrm{C}$. In 1983 , the bottom temperature was $-13.22^{\circ} \mathrm{C}$. This shift and the shift between the 1980 and 1982 temperatures are in opposite directions. The temperature was measured shortly after termination of drilling in 1980. Was the 1980 profile influenced by the drilling activities, e.g. addition of warm hole liquid? Most probably any disturbance from the drilling would have increased the hole temperature. Since no change is observed in the 200-300 m interval of the hole and the temperature in 1980 is lower than in 1982, no disturbances from the 1980 drilling activity is likely.

Below $1400 \mathrm{~m}$ the temperature gradient approaches 


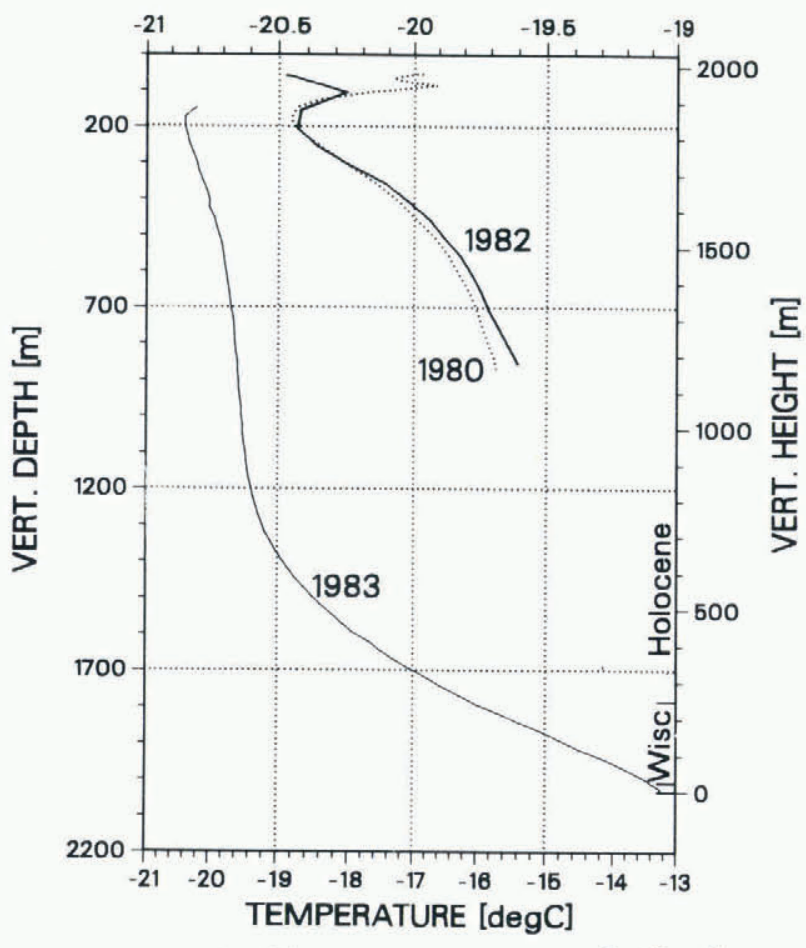

Fig. 4. Hole-liquid temperature versus depth. The expanded figure is hole temperature as measured in 1980 and 1982 at the hole wall.

$0.012 \mathrm{~K} / \mathrm{m}$ compared to $0.018 \mathrm{~K} / \mathrm{m}$ at Camp Century (Hansen and Langway, 1966; Weertman, 1968; Robin, 1983). This gradient is half the $0.024 \mathrm{~K} / \mathrm{m}$ expected in case of steady state (Paterson, 1981). There is no reason to believe that the geothermal heat is smaller in south Greenland than in Camp Century, therefore the temperature profile must be highly influenced by the past history of the ice sheet. In the last few meters above bedrock, a slight reduction in gradient is observed corresponding to the internal friction in silty ice. The temperatures in 1982 and 1983 were identical within $0.03 \mathrm{~K}$. This corresponds to the calibration accuracy of the two thermistors used. Thus, the hole is now considered to be in thermal steady state.

Since the temperature increases downwards there is a possibility of convective circulation in the hole. Based on Hales' (1937) original work, Diment (1967) and Gretener (1967) published papers on convective circulation in bore holes. Diment's nomenclature is used in the following calculation of the critical temperature gradient:

$$
G_{C}=\frac{g \alpha T}{C_{p}}+\frac{C_{v} k}{g a d^{*}}
$$

"where $G_{C}$ is the critical gradient, $g$ the acceleration due to gravity, $T$ the absolute temperature, $\alpha$ the coefficient of thermal expansion, $C_{p}$ the specific heat, $v$ the kinematic viscosity, $k$ the thermometric conductivity (diffusivity), a the radius of the tube, and $C$ is a constant which has the value 216 for a tube whose length is great compared with its diameter.

The first term in this expression is the adiabatic gradient which is about $0.2^{\circ} \mathrm{C} / \mathrm{km}$ for water and about $10^{\circ} \mathrm{C} / \mathrm{km}$ for dry air at $20^{\circ} \mathrm{C} . "$

The drill hole was filled with a mixture of jet fuel (Jet $A-1$ ) and perchlorethylene (PCE) (Gundestrup and others, in press). The thermal expansion coefficient $\alpha$ and the kinematic viscosity $\nu$ of the hole fluid at a temperature of $-15^{\circ} \mathrm{C}(T=258)$ are $9.26 \times 10^{-4} \mathrm{~K}^{-1}$ and $3 \times 10^{-6} \mathrm{~m}^{2} / \mathrm{s}$ respectively. The radius of the hole was $0.065 \mathrm{~m}$.

Data on the specific heat $C_{p}$ and diffusivity $k$ of the hole fluid are not available. Estimated values are $1.6 \times 10^{3} \mathrm{~W} \mathrm{~s} / \mathrm{kg} \mathrm{K}$ and $10^{-7} \mathrm{~m}^{2} / \mathrm{s}$ respectively. Using these figures, we obtain a critical gradient of $2 \times 10^{-3} \mathrm{~K} / \mathrm{m}$. The measured temperature gradient in the bore hole from $1750-1950 \mathrm{~m}$ is $12 \times 10^{-3} \mathrm{~K} / \mathrm{m}$, so convective circulation is not unreasonable.

On the Devon Island ice cap, Fisher (private communication) has measured convection with an amplitude of $0.1 \mathrm{~K}$ and a cell height of $8 \mathrm{~m}$ in a liquidfilled hole with a temperature gradient. of . $0.024 \mathrm{k} / \mathrm{m}$ or double that of the Dye 3 hole.

The UCPH temperature profiles did not show any sign of convection, however these profiles were obtained with a $25 \mathrm{~m}$ sampling interval. The 1982 profiles were measured with the thermistor against the hole wall so convection would not have been seen. The gradient of $0.0007 \mathrm{~K} / \mathrm{m}$ in the interval $600-900 \mathrm{~m}$ is one-third of the calculated critical gradient. But Samuel (1968) states "field measurements have shown that convective flow occurs at gradients at least an order of magnitude smaller than the calculated" (critical) "gradients". The possibility that convective flow is responsible for the $0.1 \mathrm{~K}$ warming observed at $901 \mathrm{~m}$ cannot be ruled out at this time.

\section{Directional survey}

A directional survey of a drill hole consists in measuring the inclination angle I from the vertical and the azimuthal angle $A$ from either true horth or magnetic north at measured depths $D$ along the axis of the drill hole.

The position of points along the axis of the drill hole is calculated with respect to a coordinate reference frame that has its origin at the top of the drill hole. The positive $X$ direction is east, the positive $Y$ direction is north and $Z$ is measured vertically downward.

The $X, Y$, and $Z$ coordinate of the drill hole at any measurement point $n$ are computed using the "balanced tangential equations" (Walstrom and others, 1972):

$$
x=\frac{1}{2} \sum_{i=1}^{n}\left(S_{i}-S_{i-1}\right)\left(\sin I_{i} \sin A_{i}+\sin I_{i-1} \sin A_{i-1}\right),(3)
$$$$
Y=\frac{1}{2} \sum_{i=1}^{n}\left(S_{i}-S_{i-1}\right)\left(\sin I_{i} \cos A_{i}+\sin I_{i-1} \cos A_{i-1}\right),(4)
$$

$Z=\frac{1}{2} \sum_{i=1}^{n}\left(S_{i}-S_{i-1}\right)\left(\cos I_{i}+\cos I_{i-1}\right)$,

where $I_{i}, A_{j}$, and $S_{j}$ are the inclination, azimuth and slant hole depth at measurement $i$. The slant hole depths are measured to the middle of the survey too (Blythe, 1975) which is centered in the hole by springs near top and bottom of the tool.

The PICO and UCPH survey tools contain a pair of inclinometers and a magnetic compass to measure the drill-hole inclination and azimuth. The outputs from the two inclinometers and the compass reading are used to calculate inclination and azimuth of the bore hole from magnetic north. Measurement of the magnetic deviation $\left(36^{\circ}\right.$ W.) using sun-shot and satellitedetermined positions made it possible to have the azimuth referenced to true north.

Figure 5 shows the inclination versus depth on 9 August 1981 and 2 July 1983. Above $900 \mathrm{~m}$ no change in inclination with time is visible. From 900-1784 m there is a gradual increase in the difference between the inclinations. Part of the difference may be due to the 1981 reading being too low. The 1981 inclina- 
tion was measured with the inclinometers in the drill. The drill however is not rigid and the upper part of it may not have been centered. As a consequence, readings from the drill tend to be too low, in particular at inclinations approaching the upper limit of the incl inometers $\left(6^{\circ}\right)$.

The lower part of the inclination profile is expanded in Figure 6 together with a dust profile. The

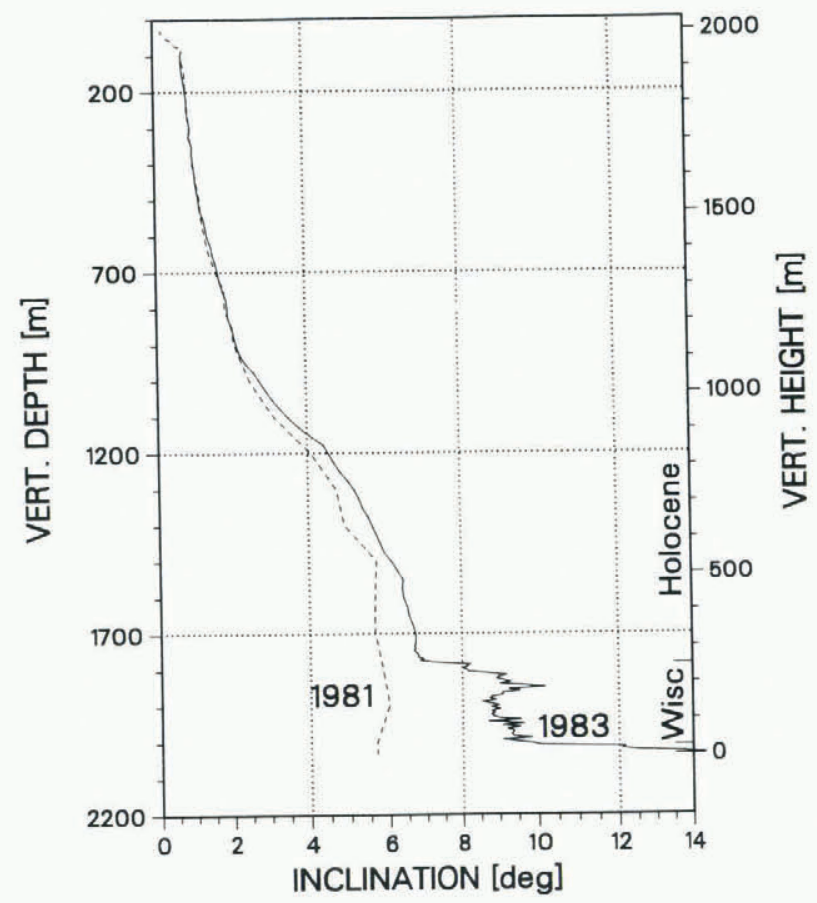

Fig. 5. Inclination versus depth. The solid line was measured 2 July 1983, dashed 9 August 1981. The 1981 inclination may be too low at higher inclinations (see text). The main part of the hole deformation occurs in Wisconsin ice.

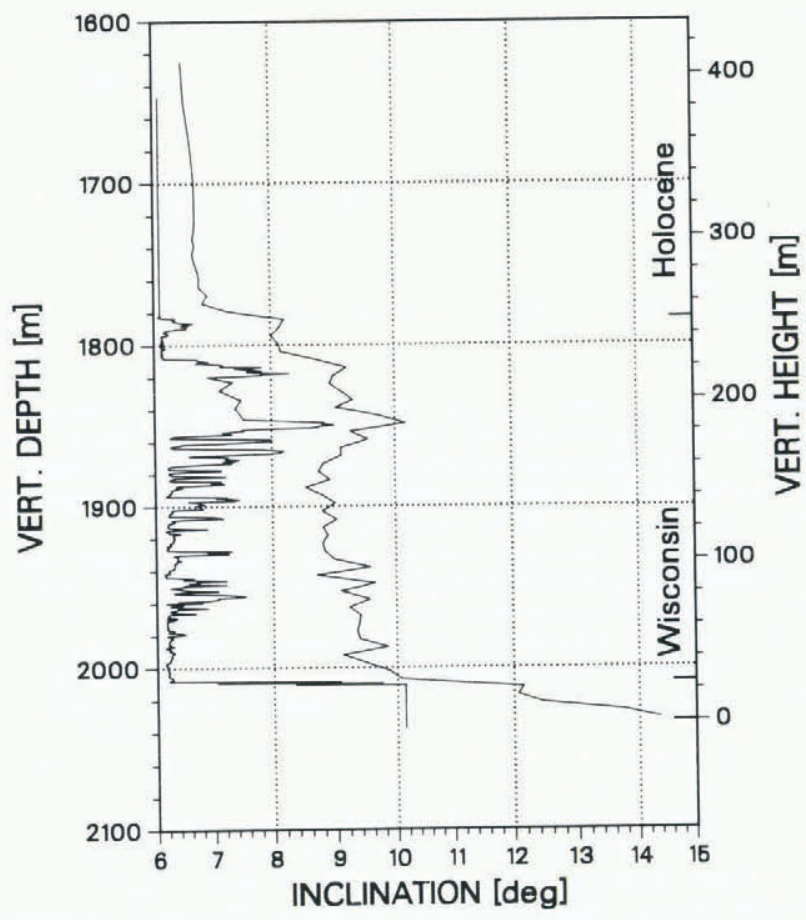

Fig. 6. Inclination versus depth below $1600 \mathrm{~m}$. The curve at left is a dust index. profile reveals the same feature as the diameter measurements (Fig. 3). There is a sharp change at the transition from the Holocene to the Wisconsin at 1783.74 m vertical depth, the Wisconsin ice showing much more deformation. Again a high correlation between dust and change in inclination is visible. The $4^{\circ}$ maximum change in inclination, occurred in the $25 \mathrm{~m}$ of silty ice over a period of 1.88 years.

Due to the $c$-axis of the ice crystals becoming more vertical with depth (Herron and others, in press) the ice is expected to creep faster with depth. Although a few measurements of the $c$-axis orientation in Wisconsin ice exists, and significant changes in $c$-axis orientation have been observed within $30 \mathrm{~m}$ (Russell-Head and Budd, 1979), change in crystal orientation can hardly explain the fast creep changes displayed in diameter and inclination. We conclude that dust, and/or some substance that varies in proportion to dust, is dominating the creep-rate, even though other physical and chemical properties vary significantly in the Wisconsin ice (Shoji and Langway, in press). This observation is supported by measurements on the Canadian ice cores (Koerner and Fisher, 1979).

The azimuth is shown in Figure 7 . The drilling was performed at nearly constant azimuth $292^{\circ} \pm 10^{\circ}$ determined by the azimuth of the casing. There is no tendency to screw shape as in the Byrd hole (Garfield and Ueda, 1976). The end of the Wisconsin corresponds to a shift of $14^{\circ}$ and silty ice to an additional $10^{\circ}$. The bottom azimuth of $260^{\circ}$ is quite consistent with the measured surface flow.

Knowing the inclination and azimuth at various depths, the $X, Y, Z$ coordinates of the drill hole were computed and plotted on a three-dimensional graph (Fig. 8). The bottom of the hole is $128.7 \mathrm{~m}$ west and $45.4 \mathrm{~m}$ north of the top of the casing. The shift between the 1980 and 1981 season at $1130 \mathrm{~m}$, and the end of the Wisconsin at $250 \mathrm{~m}$ above bedrock are clearly visible.

The horizontal velocity profile cannot be calculated due to lack of information about the 1981 hole geometry; no azimuth is known. However an estimated

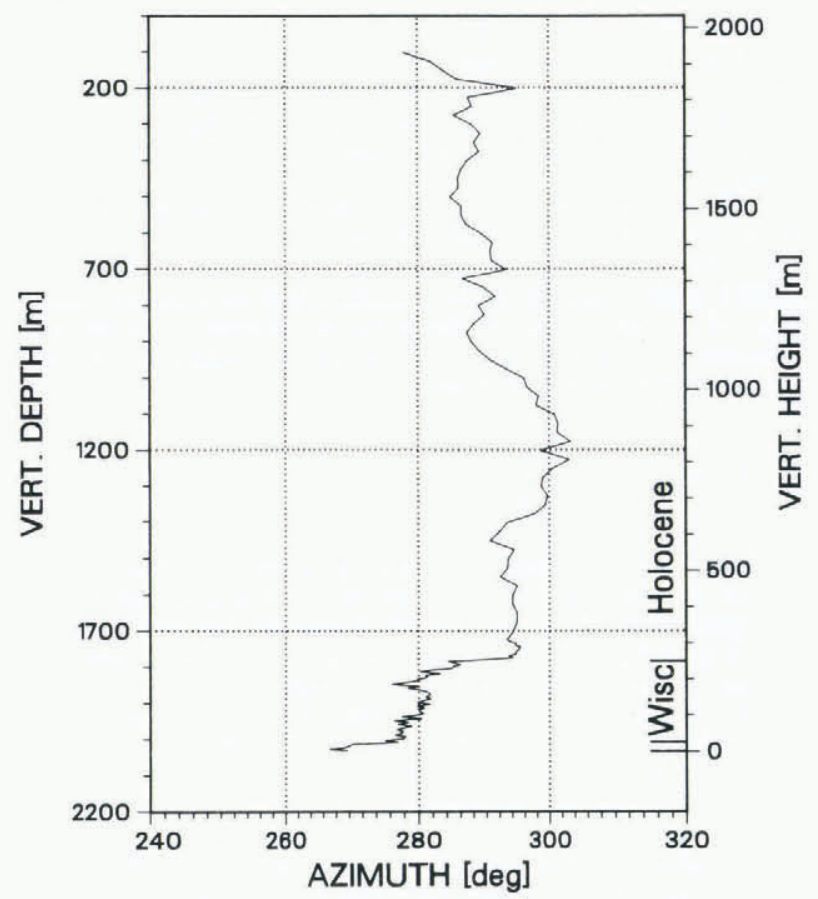

Fig. 7. 1983 azimuth versus depth. The drill hole lies almost in a plane at $290^{\circ}$ azimuth. The change in azi muth due to ice flow in Wisconsin and silty ice is clearly visible. 


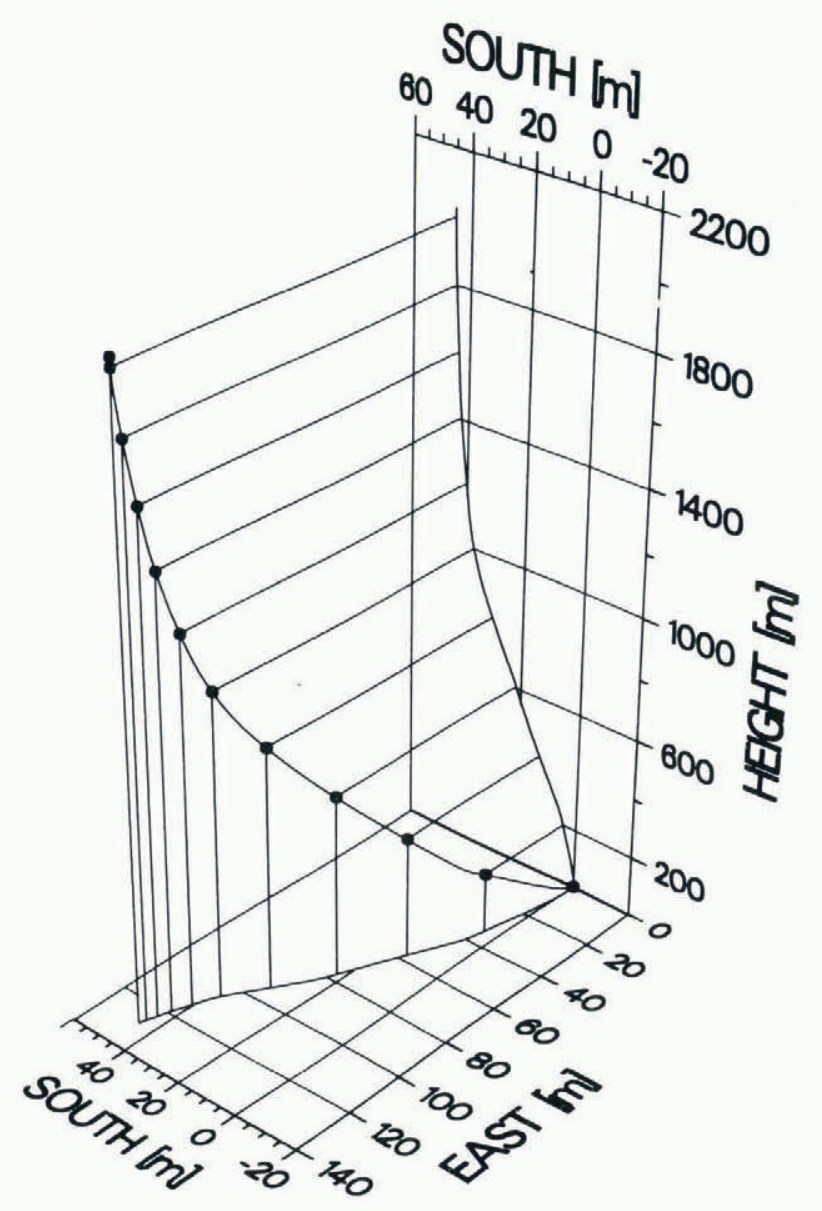

Fig. 8. Three-dimensional plot of 1983 hole position. The bottom of the hole is located north-west of the top.

profile can be computed. Figure 7 shows that the azimuth is almost constant, making it possible to estimate the 1981 azimuth: in the upper $1400 \mathrm{~m}$ above the bottom, the azimuths in 1981 and 1983 are assumed to be identical. Below $1400 \mathrm{~m}$ the azimuth in 1981 is assumed to be constant. Using this estimate, and assuming zero velocity at the bottom of the hole, the estimated horizontal velocity profile in Figure 9 is obtained. The calculated surface velocity is 13.4 $\mathrm{m} /$ year compared to the measured surface velocity of $12.3 \mathrm{~m} /$ year (Overgaard and Gundestrup, in press). The calculated azimuth is $89.5^{\circ}$ compared to a measured flow direction of $60^{\circ}$. The high surface velocity is probably due to a too small 1981 inclination below $900 \mathrm{~m}$ as explained above. Under the present circumstances, the agreement between the calculated and measured surface velocity is considered very good. Shōji and Langway (1984) have calculated a velocity profile based on estimated enhancement factors of the core, dividing the core into five sections. The profile is in reasonable agreement with the present work.

The drill did not penetrate the material below the ice. However as the calculated surface flow indicates, not many meters of ice between the bottom of the hole and the sub-ice material are missing.

The calculated velocity profile differs significantly from the theory (Dansgaard and Johnsen, 1969) where ice of temperature-dependent shear strength is assumed. Based on the calculated velocity profile and the inclination profile, four distinct flow regimes are observed: (1) above $250 \mathrm{~m}$ above bedrock corresponding to Holocene, (2) from 250-88 m above the bottom this region is assumed to contain "ordinary" Wisconsin ice, (3) from the first layer containing

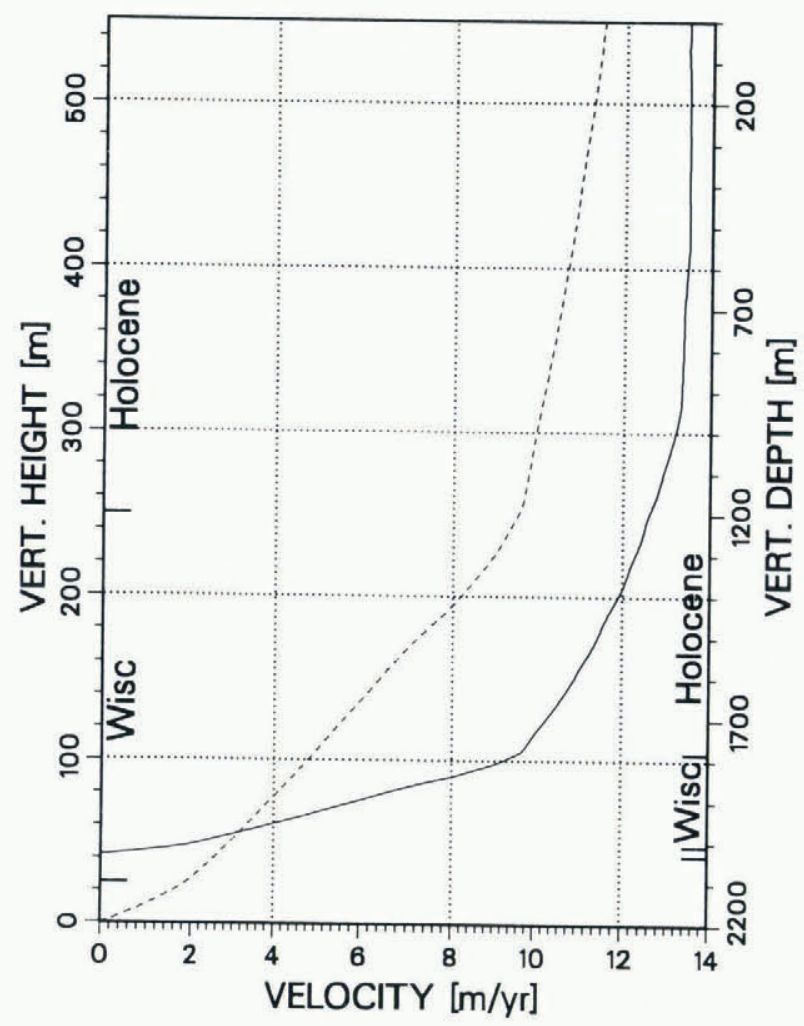

Fig. 9. Estimated horizontal ice velocity versus depth. The dashed line is the lower $500 \mathrm{~m}$ in expanded depth scale. The difference in flow enhancement factor for Holocene and Wisconsin ice is clearly visible.

bottom material at $88 \mathrm{~m}$ to silty ice at $25 \mathrm{~m}$, and (4) silty ice below $25 \mathrm{~m}$ above the bottom.

\section{SUMMARY AND CONCLUSION}

Due to the use of a two-component hole fluid, the hole fluid is inhomogeneous. Initial density differences in the hole liquid smooth very slowly and some fractionation close to the bottom cannot be excluded.

Repeated temperature measurements show the hole temperature to be in a steady state. The maximum change of temperature with depth is $0.012 \mathrm{k} / \mathrm{m}$. The bottom temperature is $-13.22^{\circ} \mathrm{C}$. Measurements indicate that the present hole temperature may deviate from that of undisturbed ice due to thermal diffusion and possible convection in the hole liquid.

The Wisconsin ice shows about an order of magnitude higher creep-rate than Holocene ice. There is a high correlation between dust and creep-rate, meaning that dust and/or some substance that varies together with dust has a major impact on the ice properties.

A velocity profile was estimated based upon assumptions about the 1981 hole position. The estimated surface velocity is $9 \%$ larger than the measured surface velocity. Holocene ice seems to flow as a homogeneous medium. Wisconsin ice and silty ice have a much higher deformation rate. The flow calculations support the assumption that the bottom of the hole is close to the sub-ice material.

Paterson (1977) and Fisher (quoted by Paterson, 1981, p. 35) found that the late Wisconsin sections of bore holes in ice caps on Devon and Ellesmere Islands, Arctic Canada, closed more rapidly than the Holocene sections. On the other hand, Paterson (1983) interpreted inclinometer measurements at Camp Century, Greenland, and Byrd Station, Antarctica, as indicating that the Wisconsin ice there deformed less readily than the Holocene ice. However, new survey of these bore holes, combined with additional surface data, might change this conclusion. 
Repeated logging of the hole will provide the data necessary to compute a measured velocity profile and possibly the average in situ ice density.

\section{ACKNOWLEDGEMENTS}

The mechanical part of the experimental UCPH logger was designed and manufactured at the H.C. Oersted Institute by $\mathrm{Mr} \mathrm{A}$. Christensen. B. Nickelsen, K. Jezek, and B. Boller assisted with the logging. The 109th Tactical Airlift Group of the New York Air National Guard provided air support. Danish Arctic Contractors helped in Sondre Strømfjord and the personnel at the Dye 3 radar station displayed their unique hospitality and patience.

This work has been sponsored by the U.S. National Science Foundation Division of Polar Programs under contract DPP74-08414, the University of Copenhagen, The Danish Commission for Scientific Research in Greenland, the Danish Natural Science Research Council, and the Commission of the European Communities under contract CLI.067.DK.

\section{REFERENCES}

Bird, I.G. [ $\left.{ }^{C} 1976.\right]$ Thermal ice drilling: Australian developments and experience. (In Splettstoesser, J.F., ed. Ice-core drilling. Proceedings of a symposium, University of Nebraska, Lincoln, 28-30 August 1974. Lincoln, London, University of Nebraska Press, p. $1-18$.

Blythe, E.J.,jr. 1975. Computing accurate directional surveys. World oil, Vol. 181, No. 2, p. 25-28.

Dansgaard, W., and Johnsen, S.J. 1969. A flow model and a time scale for the ice core from Camp Century, Greenland. Journal of Glaciology, Vol. 8, No. 53, p. 215-23.

Dansgaard, W., and others. 1975. Climatic changes, Norsemen, and modern man, by $W$. Dansgaard, S.J. Johnsen, N. Reeh, N. [S.] Gundestrup, H.B. Clausen, C.U. Hammer. Nature, Vol. 255, No. 5503, p. 24-28.

Diment, W.H. 1967. Thermal regime of a large diameter borehole: instability of the water column and comparison of air and water-filled conditions. Geophycis, Vol. 32, No. 4, p. 720-26.

Garfield, D.E., and Ueda, H.T. 1976. Resurvey of the "Byrd" Station, Antarctica, drill hole. Joumal of Glaciology, Vol. 17, No. 75, p. 29-34.

Gow, A.J. 1970. Preliminary results of studies of ice cores from the $2164 \mathrm{~m}$ deep drill hole, Byrd Station, Antarctica. [Union Géodésique et Géophysique Internationale. Association Internationale d'Hydrologie Scientifique.] [International Council of Scientific Unions. Scientific Committee on Antarctic Research. Intemational Association of Scientific Hydrology. Commission of Snow and Ice.] International Symposium on Antarctic Glaciological Exploration (ISAGE), Hanover, New Hampshire, U.S.A., 3-? September, 1968 p. 78-90. [(Publication No. 86 [de 1'Association Internationale d'Hydrologie Scientifique].)]

Gretener, P.E. 1967. On the thermal instability of large diameter wells - an observational report. Geophysics, Vol. 32, No. 4, p. 727-38.

Gundestrup, N.S., and others. In press. ISTUK a deep ice core drill system, by N.S. Gundestrup, S.J. Johnsen, and N. Reeh. CRREL Special Report (Hanover, N.H.) [Proceedings of the second International Symposium on Ice Drilling Technology, Calgary, 1982.]

Hales, A.L. 1937. Convection currents in geysers. Monthly Notices of the Royal Astronomical Society. Geophysical Supplement, Vol. 4, No. 1, p. 122-31. Hammer, C.U., and others. In press. Continuous impurity analysis along the Dye- 3 deep core, by C.U. Hammer, H.B. Clausen, W. Dansgaard, A. Neftel, P. Kristinsdottir, and E. Johnsen. (In Langway, C.C., jr, and others, ed. The Greentand Ice Sheet Program. Edited by C.C. Langway, Jr, H. Oeschger, and W. Dansgaard. Washington, D.C., American Geophysical Union. (Geophysical Monograph Series.))
Hansen, B.L., and Langway, C.C., jr. 1966. Deep core drilling in ice and core analysis at Camp Century, Greenland, 1961-1966. Antarctic Journal of the United States, Vol. 1, No. 5, p. 207-08.

Herron, S.L., and others. In press. Ultrasonic velocities and crystaliine anisotropy in the ice core from Dye-3, Greenland, by S.L. Herron, C.C. Langway, Jr, and K.A. Brugger. (In Langway, C.C., jr, and others, ed. The Greentand Ice Sheet Program. Edited by C.C. Langway, Jr, H. Oeschger, and W. Dansgaard. Washington, D.C., American Geophysical Union. (Geophysical Monograph Series.))

Jezek, K.C., and Roel offs, E.A. 1984. Measurements of radar wave speeds in polar glaciers using a downhole radar target technique. Cold Regions science and Technology, Vol. 8, No. 3, p. 199-208.

Koerner, R.M., and Fisher, D.A. 1979. Discontinuous flow, ice texture, and dirt content in the basal layers of the Devon Island ice cap. Journal of Glaciology, Vol. 23, No. 89, p. 209-22.

Overgaard, S., and Gundestrup, N.S. In press. Bedrock topography of the Greenland ice sheet in the Dye-3 area. (In Langway, C.C., jr, and others, ed. The Greentand Ice Sheet Program. Edited by C.C. Langway, $\mathrm{Jr}, \mathrm{H}$. Oeschger, and W. Dansgaard. Washington, D.C., American Geophysical Union. (Geophysical Monograph Series.))

Paterson, W.S.B. 1977. Secondary and tertiary creep of glacier ice as measured by borehold closure rates. Reviews of Geophysics and Space Physics, Vol. 15, No. 1 , p. 47-55.

Paterson, W.S.B. 1981. The physics of glaciers. Second edition. Oxford, etc., Pergamon Press. (Pergamon International L'brary.)

Paterson, W.S.B. 1983. Deformation within polar ice sheets: an analysis of the Byrd Station and Camp Century borehole-tilting measurements. Cold Regions Science and Technology, Vol. 8, No. 2, p. 165-79.

Rand, J. 1980. 1979 Greenland Ice Sheet Program, Phase 1: casing operation. CRREL Special Report (Hanover, N.H.) 80-24.

Robin, G. de Q, ed. 1983. The climatic record in polar ice sheets: a study of isotopic and temperature profiles in polar ice sheets based on a workshop held in the Scott Polar Research Institute, Cambridge. Cambridge, etc., Cambridge University Press.

Russell-Head, D.S., and Budd, W.F. 1979. Ice-sheet flow properties derived from bore-hole shear measurements combined with ice-core studies. Journal of Glaciology, Vol. 24, No. 90, p. 117-30.

Sammel, E.A. 1968. Convective flow and its effect on temperature logging in small-diameter wells. Geophysics, Vol. 33, №. 6, p. 1004-12.

Shoji, H., and Langway, C.C., jr. 1984. Flow behavior of basal ice as related to modelling consideration. Annals of Glaciology, Vol. 5, p. 141-48. Shōji, H., and Langway, C.C., jr. In press. Mechanical properties of fresh ice core from Dye-3, Greenland. (In Langway, C.C., jr, and others, ed. The Greeniand Ice Sheet Program. Edited by C.C. Langway, Jr, $H$. Deschger, and W. Dansgaard. Washington, D.C., American Geophysical Union. (Geophysical Monograph Series.))

Steinhart, J.S., and Hart, S.R. 1968. Calibration curves for thermistors. Deep Sea Research, Vol. 15, No. 4, p. 497-503.

Taylor, K.C., jr. Unpublished. Sonic logging at Dye-3, Greenland. [M.SC. thesis, University of Wiscons in-Madison, 1982.]

Walstrom, J.E., and others. 1972. A comparison of various directional survey models and an approach to model error analysis, by J.E. Walstrom, R.P. Harvey, and H.D. Eddy, Joumal of Petroleum Technology, Vol. 24, No. 8, p. 935-43.

Weertman, J. 1968. Comparison between measured and theoretical temperature profiles of the Camp Century, Greenland, borehole. Journal of Geophysical Research, Vol. 73, No. 8, p. 2691-700. 